\title{
ОЦЕНКА ДОЛГОВОЙ УСТОЙЧИВОСТИ МУНИЦИПАЛЬНОГО ОБРАЗОВАНИЯ: ПОСЛЕДСТВИЯ ВСТУПЛЕНИЯ В СИЛУ
}

\section{ASSESSMENT OF THE DEBT SUSTAINABILITY OF A MUNICIPALITY: CONSEQUENCES OF ENTRY INTO FORCE}

\section{N. Vlasova}

Summary. In the summer of 2019, the budget legislation introduces norms aimed at establishing a mechanism for assessing the debt sustainability of regional and local budgets.

The consequences of assigning a municipality to a group with a certain level of debt stability (high, medium, low) also vary.

At the same time, in the context of taking measures to prevent the spread of a new coronavirus infection, these changes had slightly different results than those that were planned.

Thus, the restrictions imposed, for example, affected the right of local self-government bodies to provide additional social support measures for certain categories of the population.

The impossibility of providing such previously established measures would predictably have a negative impact on the quality of life of the population living in the territory of the respective municipalities.

The above raises the question of correlating the validity of the changes made and their relevance in the relevant time period.

Keywords: budget legislation; assessment of the debt sustainability; municipalities; addressing local issues; additional measures of social support and social assistance for certain categories of citizens.

\author{
Власова Наталья Викторовна \\ Аспирант, Тольяттинский государственный \\ университет \\ vlasovanatalya@list.ru
}

Аннотация. Летом 2019 года в бюджетное законодательство вводятся нормы, направленные на установление механизма оценки долговой устойчивости региональных и местных бюджетов.

Последствия отнесения для муниципального образования к группе с определенным уровнем долговой устойчивости (высокая, средняя, низкая) также варьируются.

Вместе с тем, в условиях принятия мер по недопущению распространения новой коронавирусной инфекции данные изменения имели несколько иные результаты, чем те, которые были запланированы.

Так, вводимые ограничения, например, коснулись права предоставления органами местного самоуправления дополнительных мер социальной поддержки для отдельных категорий населения.

Невозможность предоставления таких ранее установленных мер прогнозируемо негативно бы отразилась на качестве жизни населения, проживающего на территории соответствующих муниципальных образований.

Изложенное ставит вопрос соотнесения обоснованности вносимых изменений и их актуальности в соответствующий период времени.

Ключевые слова: бюджетное законодательство; оценка долговой устойчивости; муниципальные образования; решение вопросов местного значения; дополнительные меры социальной поддержки и социальной помощи для отдельных категорий граждан.

\section{«Ф} едеральным законом от 02.08.2019 № 278Ф3 «О внесении изменений в Бюджетный кодекс Российской Федерации и отдельные законодательные акты Российской Федерации в целях совершенствования правового регулирования отношений в сфере государственных (муниципальных) заимствований, управления государственным (муниципальным) долгом и государственными финансовыми активами Российской Федерации и признании утратившим силу Федерального закона «Об особенностях эмиссии и обращения государственных и муниципальных ценных бумаг»» [1] в «Бюджетный кодекс Российской Федерации» [1] (далее - БК РФ) введена статья 107.1, направленная на регулирование отношений, связанных с «оценкой долговой устойчивости субъекта Российской Федерации и муниципального образования» [1].

Согласно пояснительной записке к проекту Федерального закона №609452-7 данный законопроект разработан с учетом оптимальных практик в сфере управления государственными заимствованиями через введение классификации групп долговой устойчивости субъектов Российской Федерации и муниципальных образований (высокая, средняя, низкая) путем установления новых критериев долговой устойчивости и их значений. 
Таким образом, законодатель выстраивал путь необходимости проведения публично-правовыми образованиями ответственной заемной (долговой) политики.

Так, отнесение публично-правового образования к той или иной группе долговой устойчивости предлагалось осуществлять исходя из определения значений следующих показателей:

- «объем долга к общему объему доходов соответствующего бюджета без учета безвозмездных поступлений (безвозмездных поступлений и (или) поступлений налоговых доходов по дополнительным нормативам отчислений от налога на доходы физических лиц)» [1];

- «годовая сумма платежей по погашению и обслуживанию долга, возникшего по состоянию на 1 января очередного финансового года, без учета платежей, направляемых на досрочное погашение долговых обязательств со сроками погашения после 1 января года, следующего за очередным финансовым годом, к общему объему налоговых и неналоговых доходов соответствующего бюджета и дотаций из бюджетов бюджетной системы Российской Федерации» [1];

- «доля расходов на обслуживание долга в общем объеме расходов соответствующего бюджета, за исключением объема расходов, которые осуществляются за счет субвенций, предоставляемых из бюджетов бюджетной системы Российской Федерации» [1].

В зависимости от отнесения публично-правового образования к той или иной группе долговой устойчивости последствия также разделялись по их «строгости».

Так, например, публично-правовые образования группы заемщиков «с высоким уровнем долговой устойчивости освобождались от необходимости согласования с Минфином России (финансовым органом субъекта Российской Федерации) программ государственных (муниципальных) заимствований и гарантий» [1].

«На публично-правовые образования, отнесенные к группе заемщиков со средним уровнем долговой устойчивости, налагалась обязанность согласования с соответствующим финансовым органом программ государственных (муниципальных) заимствований и гарантий, а также представления в этот орган проекта основных направлений долговой политики» [1].

«Публично-правовые образования, отнесенные к группе заемщиков с низким уровнем долговой устойчивости, были вправе осуществлять рыночные заимствования только в целях рефинансирования долга.
Помимо обязанности согласования с Минфином России (финансовым органом субъекта Российской Федерации) программ государственных (муниципальных) заимствований и гарантий, представления проекта основных направлений долговой политики, на них также налагалась обязанность утверждения и реализации, согласованного с Минфином России (финансовым органом субъекта Российской Федерации) плана восстановления платежеспособности» [1].

02.08.2019 был принят Федеральном законе № 278Ф3, в котором нашли отражение данные положения.

Кроме того, последствиями отнесения муниципального образования к группе заемщиков со средним уровнем долговой устойчивости, в том числе, стало применение к нему требований, предусмотренных пунктами 2 и 3 статьи 136 БК РФ.

Так, согласно пункту 3 статьи 136 БК РФ такие «муниципальные образования начиная с очередного финансового года не имеют права устанавливать и исполнять расходные обязательства, не связанные с решением вопросов, отнесенных к полномочиям соответствующих органов местного самоуправления» [1].

Указанные ограничения, в частности, распространяются на «установление муниципальным образованием права осуществлять расходы за счет средств бюджета муниципального образования на осуществление полномочий, не переданных им в соответствии со статьей 19» [2] Федерального закона от 06.10.2003 № 131-Ф3 «Об общих принципах организации местного самоуправления в Российской Федерации».

«Частью 5 статьи 20 Федерального закона от 06.10.2003 № 131-Ф3 «Об общих принципах организации местного самоуправления в Российской Федерации» предусмотрено право установления органами местного самоуправления за счет средств бюджета муниципального образования дополнительных мер социальной поддержки и социальной помощи для отдельных категорий граждан вне зависимости от наличия в федеральных законах положений, устанавливающих указанное право» [2].

При этом, руководствуясь данным положением, во многих муниципальных образованиях до введения оценки долговой устойчивости были установлены такие дополнительные меры социальной поддержки с учетом определения категории граждан исходя из их нуждаемости в направлениях поддержки, а также возможностей местного бюджета.

Как показывает практика, дополнительные меры социальной поддержки устанавливались как в интересах 
непосредственно муниципального образования, а также в интересах органов государственной власти Российской Федерации (с учетом исполняемых полномочий и возникающих спорных вопросов на соответствующей территории).

Во многих муниципальных образованиях практика предоставления дополнительных мер социальной поддержки также была многолетней и имела выраженный общественно значимый характер, так как благополучателями указанных мер традиционно являлись малоимущие семьи, дети-сироты, дети, рожденные от ВИЧ-инфицированных матерей, ветераны Великой Отечественной войны, инвалиды, жертвы политических репрессий, и др.

Таким образом, отнесение муниципального образования с 01.01.2021 (изначально установленной даты вступления в силу Федерального закона от 02.08.2019 № 278-Ф3 в указанной части) к заемщикам со средним уровнем долговой устойчивости делало невозможными предоставление установленных дополнительных мер социальной поддержки.

Изложенное могло повлечь кризисную ситуацию и создать социальную напряженность, что особенно необходимо было избегать в существующих условиях.

Так, Президентом Российской Федерации были введены беспрецедентные меры в связи с недопущением распространения новой коронавирусной инфекции, в том числе включающие в себя ряд выплат семьям, имеющим детей.

В настоящее время Федеральным законом от 15.10.2020 № 327-Ф3 «О внесении изменений в Бюджетный кодекс Российской Федерации и отдельные законодательные акты Российской Федерации и установлении особенностей исполнения бюджетов бюджетной системы Российской Федерации в 2021 году» положения статьи 107.1 БК РФ в части установления рассмотренных выше ограничений приостановлены до 01.01.2022.

\section{ЛИТЕРАТУРА}

1. Бюджетный кодекс Российской Федерации от 31.07.1998 № 145-Ф3 // Собрание законодательства РФ. 03.08.1998. № 31. ст. 3823.

2. Федеральный закон от 06.10.2003 № 131-Ф3 «06 общих принципах организации местного самоуправления в Российской Федерации» // Собрание законодательства Российской Федерации. 06.10.2003. № 40. ст. 3822.

3. Федеральный закон от 02.08.2019 № 278-Ф3 «0 внесении изменений в Бюджетный кодекс Российской Федерации и отдельные законодательные акты Российской Федерации в целях совершенствования правового регулирования отношений в сфере государственных (муниципальных) заимствований, управления государственным (муниципальным) долгом и государственными финансовыми активами Российской Федерации и признании утратившим силу Федерального закона «0б особенностях эмиссии и обращения государственных и муниципальных ценных бумагш» // 0фициальный интернет-портал правовой информации http://www.pravo.gov.ru. 02.08.2019; Собрание законодательства РФ. 05.08.2019. № 31. ст. 4437; Российская газета. 09.08.2019. № 175.

4. Федеральный закон от 15.10.2020 № 327-Ф3 «0 внесении изменений в Бюджетный кодекс Российской Федерации и отдельные законодательные акты Российской Федерации и установлении особенностей исполнения бюджетов бюджетной системы Российской Федерации в 2021 году» // 0фициальный интернет-портал правовой информации http://www.pravo.gov.ru. 15.10.2020; Собрание законодательства РФ. 19.10.2020. № 42 (часть II). ст. 6514 ; Российская газета. 20.10.2020. № 236.

5. Указ Президента РФ от 20.03.2020 № 199 «0 дополнительных мерах государственной поддержки семей, имеющих детей» // Официальный интернет-портал правовой информации http://pravo.gov.ru. 20.03.2020; Собрание законодательства РФ. 23.03.2020. № 12. ст. 1745.

6. Указ Президента РФ от 07.04.2020 № 249 «0 дополнительных мерах социальной поддержки семей, имеющих детей» // Официальный интернет-портал правовой информации http://pravo.gov.ru. 07.04.2020; Собрание законодательства РФ. 13.04.2020. № 15 (часть I). ст. 2243.

7. Постановление администрации городского округа Самара от 14.11.2017 № 981 «0б утверждении муниципальной программы городского округа Самара «Социальная поддержка инвалидов, ветеранов и граждан пожилого возраста» на 2018-2022 годы» // Сайт администрации городского округа Самара https://samadm.ru/docs/official-publication. 18.11.2017.

8. Постановление администрации городского округа Тольятти от 13.09.2019 № 2488-п/1 «0б утверждении муниципальной программы «Создание условий для улучшения качества жизни жителей городского округа Тольятти» на 2020-2024 годы» // газета «Городские ведомости». № 70. 20.09.2019.

9. Проект Федерального закона № 609452-7 «0 внесении изменений в Бюджетный кодекс Российской Федерации и отдельные законодательные акты Российской Федерации в целях совершенствования правового регулирования отношений в сфере государственных (муниципальных) заимствований, управления государственным (муниципальным) долгом и государственными финансовыми активами Российской Федерации и признании утратившим силу Федерального закона «06 особенностях эмиссии и обращения государственных и муниципальных ценных бумаг»» // https://sozd.duma.gov.ru/ bill/609452-7.

(с) Власова Наталья Викторовна ( vlasovanatalya@list.ru )

Журнал «Современная наука: актуальные проблемы теории и практики» 